Article

\title{
How to Promote University Students to Innovative Use Renewable Energy? An Inquiry-Based Learning Course Model
}

\author{
Xingwei Wang and Liang Guo *(D) \\ College of Control Science and Engineering, China University of Petroleum (East China), \\ Qingdao 266580, Shandong, China; 13153286426@163.com \\ * Correspondence: guoliang@upc.edu.cn; Tel.: +86-0532-8698-3326
}

\section{check for}

updates

Citation: Wang, X.; Guo, L. How to Promote University Students to Innovative Use Renewable Energy? An Inquiry-Based Learning Course Model. Sustainability 2021, 13, 1418. https://doi.org/10.3390/su13031418

Academic Editor: Jordi Colomer Feliu Received: 29 December 2020

Accepted: 22 January 2021

Published: 29 January 202

Publisher's Note: MDPI stays neutral with regard to jurisdictional claims in published maps and institutional affiliations.

Copyright: (c) 2021 by the authors. Licensee MDPI, Basel, Switzerland. This article is an open access article distributed under the terms and conditions of the Creative Commons Attribution (CC BY) license (https:// creativecommons.org/licenses/by/ $4.0 /)$.

\begin{abstract}
This paper aims to explore a student-oriented curriculum model on Renewable Energy Sources (RES), since RES is an important solution to the energy problem, and training talents with relevant skills and qualities has become a key part of our overall energy strategy. Based on Taylor Principle and PDCA Cycle Theory (Plan, Do, Check, Act), this paper proposed a "Student-centered Inquiry" RES course model together with three reference templates for the design, teaching, and evaluation processes of the course. This dissertation conducted a case study on 27 students from China University of Petroleum (East China), and the primary purpose of the study was to find out how changes in the curriculum could affect the learning effects of both high achievement students and low achievement students. By adopting the paired T-test and independent T-test, the results indicated that: (a) There was a relationship between the new curriculum model and the students' academic performance, (b) the improvement in low-achievement students was more significant than in high-achievement students, and (c) the new curriculum model has positive effects on students in terms of knowledge transfer, methodology, reductionism, and consciousness formation. In view of the limitations of current RES related education in universities, these results can be used as templates to improve the quality of RES education.
\end{abstract}

Keywords: renewable energy; curriculum model; inquiry-based learning; case study; effect test

\section{Introduction}

\subsection{Background Information}

Since the 21st century, the energy crisis and environmental problems have become increasingly prominent, affecting the economic and social development as well as the improvement in quality of life in all countries [1]. To solve energy shortage and reduce environmental pollution fundamentally, many countries in the world have given priority to the development and promotion of technologies for access to clean and renewable energy sources (RES) [2-4]. The development and promotion of renewable energy technologies are inseparable from public support and talent training [5]. At present, one major obstacle to the promotion of RES technology is the lack of talent with RES innovation awareness and ability [6,7]. Education is an effective way to cultivate the public's awareness and achieve professionalization [8,9]. Research shows that most people have a basic awareness of the energy crisis and environmental pollution [8,10], but the sensitivity of this awareness needs to be strengthened through education [11]. Therefore, improving people's awareness through education is an effective way to overcome the obstacles to the promotion and innovative using of RES [12-14].

Higher education is the cradle of cultivating students, through which the social needs can be positively met $[15,16]$. Since the 1970s, many countries have been actively implementing RES education programs at the stage of higher education [16]. However, there are still some problems in the current RES curriculum, which can be classified into three categories: the design, teaching, and evaluation of the course. At the design stage, it is difficult for course designers to demonstrate the integrity and effectiveness of the curriculum, 
as they cannot find relevant guidance from past cases. In the process of teaching, many teachers emphasize theory over practice, which is contrary to the teaching goal [17]. As for the evaluation process, a written test is more used to evaluate the effect of learning, while it cannot measure the improvement of students' ability comprehensively [18]. All these problems challenge us to rethink the curriculum model of RES.

This work chose China as the research object. As the world's largest energy consumer, China has recognized the importance of RES education. The Renewable Energy Law of the People's Republic of China stipulates that in order to develop renewable energy, the Education Administration Department of the State Council should incorporate renewable energy knowledge and technology into the general education and vocational education courses, which highlights the importance of the development of RES courses.

\subsection{Structure of the Dissertation}

The literature review section starts off with a discussion on the current status of RES courses in the world, it then reviews the status and issues with current RES courses in the Chinese context. To address these issues in detail, the following section analyses the model content in detail, then it introduces the theoretical basis of the model, and finally worked out a "Student-centered Inquiry" course model on RES as well as three reference templates from the design, teaching and evaluation perspectives. Section 4 introduces a curriculum case and conducts a quantitative analysis of the learning effect. Finally, the last section further discusses the results of the study and summarizes the conclusions. The limitations of this research are demonstrated and recommendations for future research are also made in the end.

\subsection{Objectives}

The aim of the research will be to design a new RES curriculum model that meets the needs of RES talents; explore the learning effects of students on RES courses and compare the different effects between high-achievement and low-achievement students; develop the students' awareness of RES and provide suggestions for the current curriculum model.

\section{Literature Review}

\subsection{Status of Renewable Energy Courses}

Many countries in the world have previously focused on implementing RES and environmental education programs. They work hard to develop courses in the field of new energy [19]. It is undeniable that RES courses for college students are now universal [16]. However, they are mostly embodied in the form of independent graduate academic programs [20-23] and have not yet been generally accepted for undergraduates. Kandpal and Broman pointed out that although the undergraduate RES courses are not as mature as the graduate level, they have already been offered in the United States, the United Kingdom, Germany, Italy, and other countries [24]. In addition, an obvious problem exists in RES courses in universities all over the world, that is, the curriculum limitation and update lag $[25,26]$. There is still much room for improvement in the university RES courses, which is seriously inconsistent with the urgent needs of talents in the field of RES in the international community.

The sustainable and rapid development of China is inseparable from its huge energy resource reserves. In order to fundamentally eliminate the key obstacles such as the shortage of RES technology and lay a foundation for the sound development of RES in China in the future, it is necessary to find new solutions from the educational level [27]. However, the current RES education in China is far from meeting the expectations and the speed of its development cannot provide strong support for the growth of the country's actual energy production and consumption. Due to the limited number of teachers in the field of renewable energy, the RES curriculum has not received enough attention and its development form is still the same as the traditional indoctrination teaching model [17]. Traditional teaching, which emphasizes theory over practice and teaching over inquiry, runs 
counter to the goal of skill training and attitude change in RES education. Simultaneously, most colleges have refined the RES curriculum into wind energy, solar energy, and biomass energy related courses. They have higher orientation characteristics and are inferior to British and American countries in terms of subject integration [28-30]. In addition, the subjectivity in curriculum content selection, the derailment of teaching and social needs, and the emphasis on written examination rather than the learning process are factors that cannot be ignored, as they directly affect the quality of RES education and the realization of RES education goals [18]. The RES courses in China's universities need further optimization and standardization to ensure that the development of the energy industry continues to transport cutting-edge talents with the help of high-quality course teaching.

\subsection{The Problems of Current RES Courses}

RES education involves multi-disciplinary knowledge and requires students to have a strong innovative ability to explore and solve practical problems, which, therefore, poses a great challenge to the development of school-related courses [31]. The existing course content can be divided into three categories: the definitions and properties of RES, the principle and performance of RES devices, related manufacturing issues, and the innovative use of RES [32-34]. It is known that the curriculum is strictly limited to theory and skills, but simple knowledge transfer cannot systematically cultivate college students' awareness of RES use. Based on the existing literature, this work reviews the problems in the design, teaching, and evaluation processes of the RES curriculum.

Firstly, subjective bias is a typical problem in the design process of RES courses. Its impact contains two aspects. On the one hand, the design of course content and construction of the current RES curriculum usually depend on the professional knowledge of teachers rather than the needs or interests of students. In this process, the teachers professional knowledge is often overemphasized [24]. The subjective bias of curriculum design leads to the failure to implement a student-centered curriculum, which ignores the subjective initiative of learners as well as the inconsistencies between the skills required for employment and the knowledge acquired in classes [35]. Harrovon and others, when analyzing the curriculum reform process of the Chemical Engineering major at Cape Town University, pointed out that most of the teachers are inclined to theoretical teaching and fail to cultivate students' ability to independently explore solutions [36]. On the other hand, the interdisciplinary and exploratory features of sustainable RES education are ignored [37]. In the limited course time, students are not allowed to explore the problem independently. Kandpal and Broman concluded that the current university RES curriculum generally has the problem of "broadness without depth" [24]. Compared with RES courses in primary and secondary schools, undergraduate education shows no significant breakthrough in inspiring students to explore independently and deeply. The subjective bias and trade-off between breadth and depth are prominent problems in the current RES curriculum design.

Secondly, in the course teaching stage, there is a lot of space for improvement in the teacher's role and teaching mode. The goals of RES education include developing learners' awareness of RES use, forming values, and cultivating students to develop and implement alternative strategies to meet the challenges [24]. However, when RES education courses enter universities, teachers often automatically include RES courses in the scope of traditional courses. This teaching method fails to achieve the goal of developing problemsolving ability and RES awareness. Instead, what is needed is a teaching method in which teachers act as auxiliary guides and students participate as active explorers. Sinnema et al. [37] and Dobber et al. [38] both emphasized the importance of student active inquiry teaching.

Lastly, the evaluation mechanism is an extremely important part of education. As early as 1979, JL Miller [39] summarized that the teacher's evaluation of students in energy courses mainly includes three aspects: the students' understanding of the importance of energy, the realization of technical goals, and the interest level of students. This clearly reflected the diversified requirements of energy related curriculum evaluation from the 
content. Youakim Al Kalaani [40] asked students to complete a detailed written report and make oral presentations. At the same time, the teacher needed to prepare a summary of the whole learning experience including student evaluation, which reflected the diversity in form and subject. However, contrary to the ideal situation, the assessment of existing RES education courses in China is mostly focused on written tests, lacking process evaluation and application evaluation. The evaluation mechanism only guides students to accumulate knowledge and ignores the flexible use of related knowledge and skills. Therefore, it lacks core competitiveness. This also explains the employment difficulties for graduates of existing disciplines in the energy field, that is, the skills acquired by students do not meet the requirements of the RES industry [41,42].

To sum up, although current RES courses are more and more valued by the school, and the content and form of the curriculum are also showing diverse characteristics. It should be more concerned that there are still many problems in the development of RES courses. The traditional curriculum model is to be optimized to meet the needs of RES personnel training. The three main processes of curriculum design, teaching, and evaluation need to be systematically improved. Therefore, this article firstly clarifies the curriculum goals, taking the cultivation of RES awareness as the core, then refers to the capacity requirements in the sustainable development goals, and finally proposes a systematic RES curriculum development plan.

\section{Construction of RES Course Model}

The whole process of RES courses should focus on cultivating students' attitudes and technologies for the innovative use of RES. Through the integration of innovative, practical, technological, and exploratory courses, students are allowed to exercise their skills in autonomous inquiry and change their attitude in problem-solving [43]. According to the current problems mentioned in the literature review, this work first divided the RES curriculum model into three sections: design, teaching, and evaluation, it then worked out corresponding reference templates for each section to solve the current problems. Finally, all three sections were systematically integrated into a "student-centered inquiry" model for renewable energy curriculum.

\subsection{Theoretical Basis of RES Course Model Construction}

In order to match the core curriculum goals-innovative use of energy technology and attitude change towards energy, this paper took the teaching theory of John Dewey as its theoretical basis, since its two principles, "Practical Principles" and "Personalization Principles", highly matched the curriculum development needs of renewable energy [43-45].

In addition, the current guidelines for RES courses are fragmented in terms of design, teaching, and evaluation, which is clearly detrimental to the overall development of RES education $[6,20,46]$. Therefore, it is particularly important to develop a set of standardized RES courses with reference value. According to the well-known "Taylor Principle", the curriculum can be divided into four major links: identifying educational goals, choosing learning experiences, organizing educational experiences, and evaluating educational experiences [47]. Its clear link division can make the content standardized and operable. Aiming at the characteristics of RES education-high practical requirements and emphasis on the cultivation of consciousness, this work adjusted on the standardized process of the "Taylor Principle" division. The whole process of RES curriculum development is divided into three major links: design, teaching, and evaluation. At the same time, by introducing the PDCA Cycle Theory of management these three links were systematically integrated.

\section{2. "Student-Centered Inquiry" Course Model on Renewable Energy}

The integration of PDCA theory makes the original RES curriculum links coherent and finally form a systematic curriculum model system-The "Student-centered Inquiry" Course Model on Renewable Energy. As shown in Figure 1, "P" refers to the curriculum design that is based on sustainable development goals and focused on students' positive 
attitudes towards RES and professional technology. " $\mathrm{D}$ " means project-oriented teaching based on the target needs of the RES curriculum. " $\mathrm{C}$ " refers to the multidimensional evaluation plan of students on RES theory, skills, and cognition. " $\mathrm{A}$ " is the action of summarizing and optimizing the course model by connecting the evaluation and design processes and through analysis of multi-variable feedback such as student response and RES research orientation.

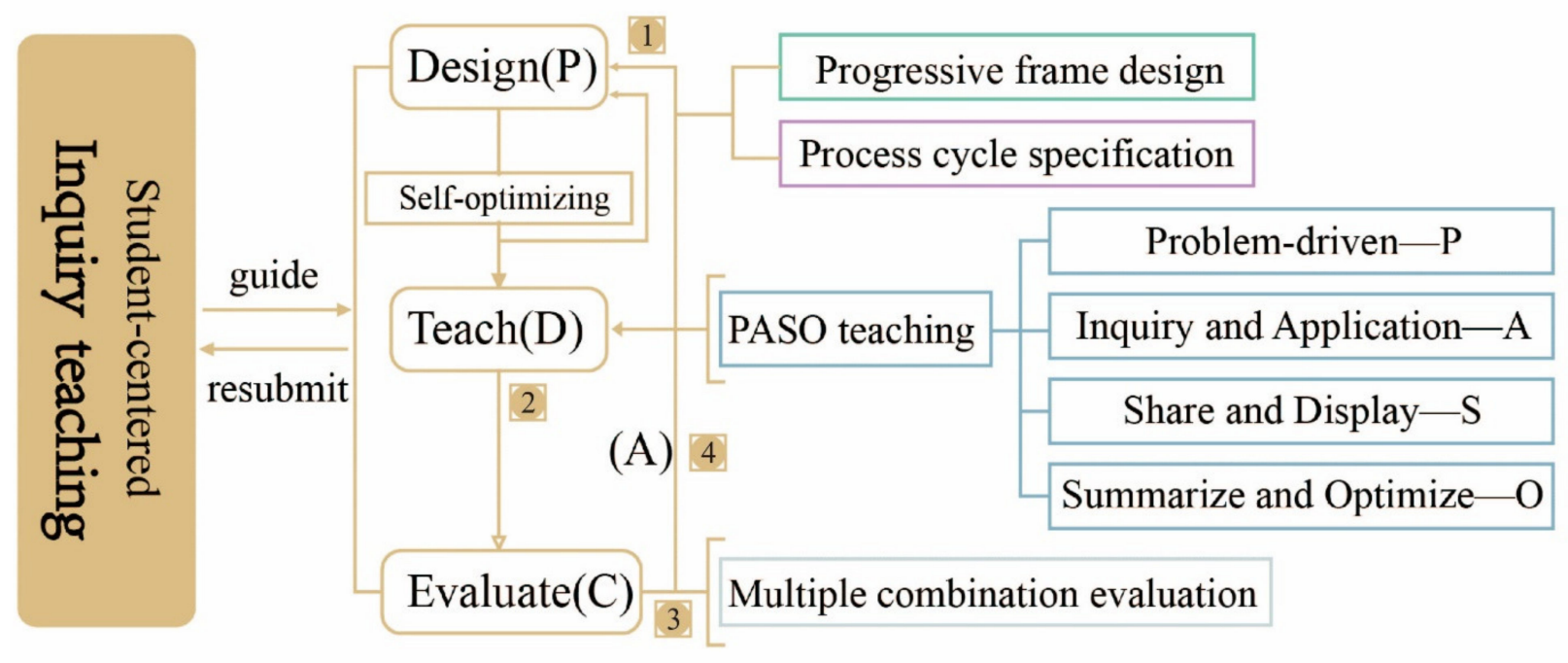

Figure 1. "Student-centered Inquiry" Course Model on Renewable Energy:(1) Design(P), (2) Teach(D), (3) Evaluate(C), (4) Act and Optimize (A).

\subsection{Specific Templates for Three Processes}

\subsubsection{The Template for Course Design Process}

When designing a course, developers need to follow appropriate guidelines to fully guarantee the accuracy of its content and scope [24]. One of the outstanding problems in the current RES course design is that it still focuses on the transfer of single-disciplinary theoretical knowledge, with no in-depth consideration of its interdisciplinary and applicability characteristics. This makes the implementation of the core goals of the RES course (attitude change and technology training) still unsatisfactory. In addition, as described in the literature review, there are still problems in the design of RES courses such as "experience-oriented", "derailed from actual needs", and "ignoring the academic background of multidisciplinary integration". With the specific goal of guiding students to build a framework of RES capabilities based on their existing experience, a corresponding optimization mechanism for the design process is formulated. The mechanism consists of a "progressive design of course content" that clarifies the course content and a "six-step curriculum design process template" that optimizes the curriculum design.

1. Progressive design of course content

The broad goal of RES education is to provide practical knowledge for college students to understand the facts, concepts, principles, and techniques of using RES. According to the progressive learning habits and acceptance ability of students, scholars split them into the following four levels of goals to standardize the content system and ensure the quality of the curriculum, which is also shown in Figure 2.

- (First goal) To cultivate students' understanding of the nature and causes of energy problems, such as fossil fuel shortage and climate change issues.

- (Second goal) To make students aware of the resource potential of various types of non-renewable and renewable energy sources, and understand the economics and econometrics related to renewable energy technologies and the social, cultural, environmental, and institutional issues related to the development and use of renewable energy technologies. 
- (Third goal) To motivate and train students to implement alternative strategies to meet energy challenges, including using environmentally friendly and sustainable RES sources to meet the growing global energy needs.

- (Fourth goal) To develop students' values and attitudes towards the innovative use of RES.

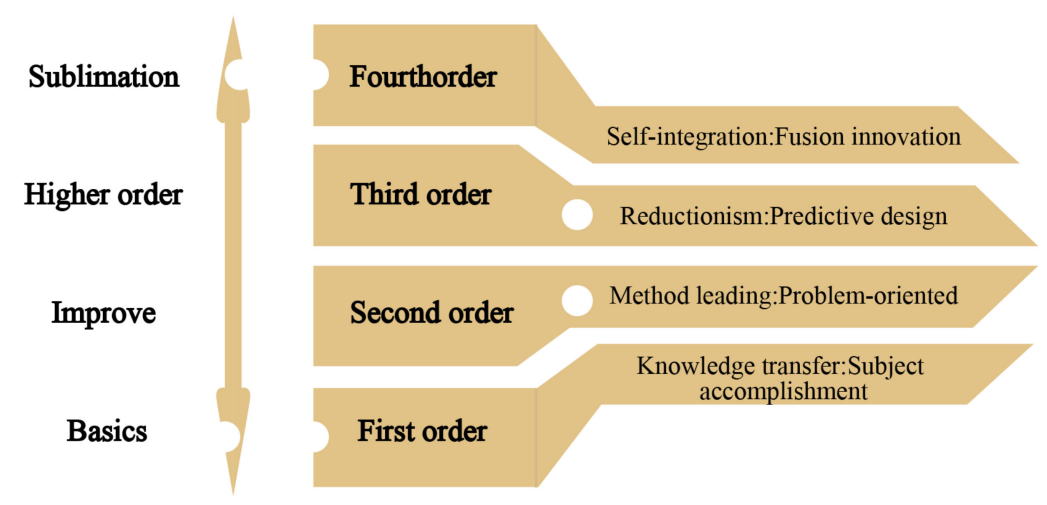

Figure 2. Progressive Design of Course Content.

\section{Six-step Curriculum Design Process Template}

Figure 3 shows the "six-step curriculum design process template", which was based on the existing RES curriculum development processes in universities. As the name indicates it consists of six steps, namely, subject identification, subject analysis, program planning, implementation preparation, course evaluation, and achievement formation.

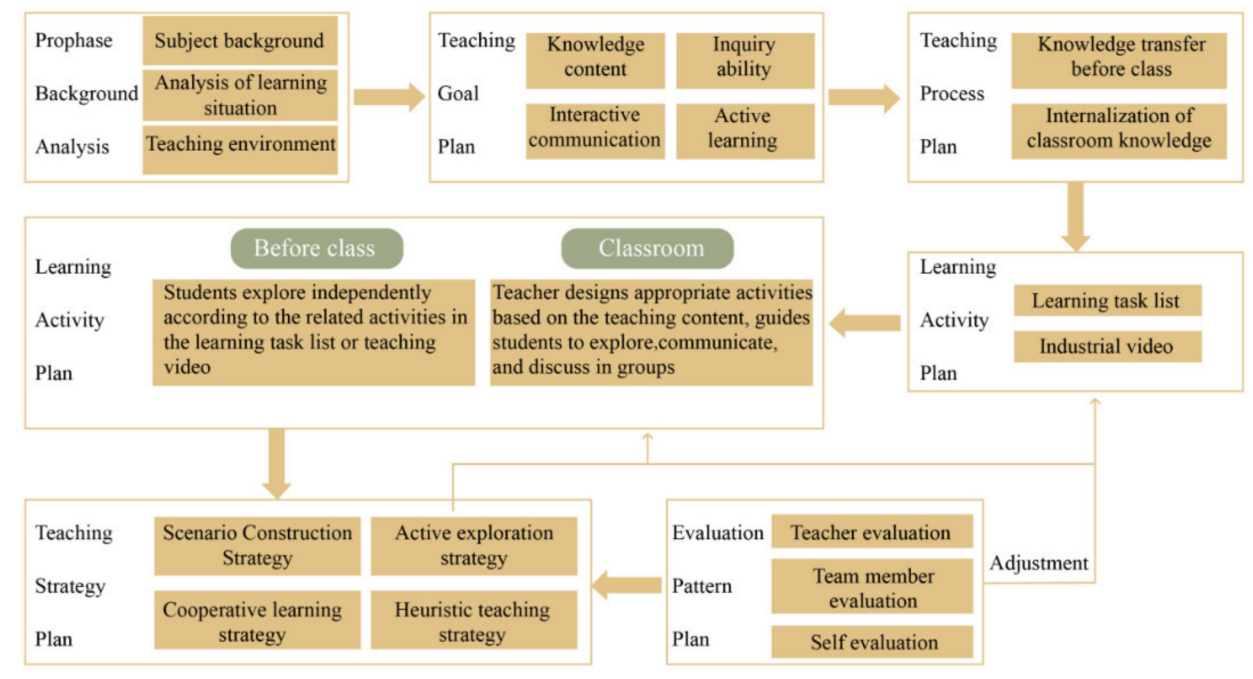

Figure 3. Six-step Curriculum Design Process Template.

When determining topics related to RES, the first thing to do is identify the real problems and needs to make the course more practical. At the same time, it is equally important to take in the views of everyone and set up sub-topics under the main theme according to students' interests. Therefore, practical basis and interest tolerance are important to experience in establishing a topic. Project analysis is to combine the conditions required for RES project research with actual resources such as school personnel, policies, and facilities. After matching topics with resources, teachers can proceed with specific development plans for RES courses. In addition, the effect evaluation should be conducted in time to verify the scientific nature and effectiveness of the RES curriculum. Finally, teachers participating in RES teaching must propose targeted modifications based on students' feedback and the guidelines of social RES research, so as to optimize the current stage. 
There are two points to note when completing the above steps in RES course development. First, the role of each participant is not fixed or single and should be adjusted in real-time according to the actual situation of the project. Second, after the completion of a process and before entering the next six-step cycle, the existing RES curriculum model should be adjusted and optimized in a timely manner according to the evaluation feedback and observation in the implementation process.

\subsubsection{The Template for Course Teaching Process}

The university's renewable energy curriculum encourages students to explore independently, propose new questions about the current state of RES, come up with new ideas for solving problems, and finally work out solutions from existing experience to turn ideas into actions. In the process of dynamic social change, the role of teachers should also be re-positioned. For university RES courses, teachers should not only be the translators of knowledge but also guiders to promote the development of the world's RES research [48-52]. Due to the limited teaching experience and professional cognition of teachers in RES courses, in practice, there are obvious problems such as incorrect role positioning, backward teaching methods, and insufficient attention. To address the above teaching problems, this work designed the PASO teaching method based on PBL Theory (Project-Based Learning), whose core lies in clarifying the specific content of the curriculum and improving teachers' understanding of the nature of RES education for college students on the premise of adhering to the student-centered education concept. The PASO teaching method promotes the students to develop the habit of independent learning and cooperative inquiry by giving full play to their subjective initiative in the teaching process. As shown in Figure 4, the PASO teaching method divides the teaching process into the following four steps:

\begin{tabular}{|l|}
\hline Problem-driven (P) \\
\hline Problem \\
Determine the \\
theme \\
Find problems
\end{tabular}

(a)

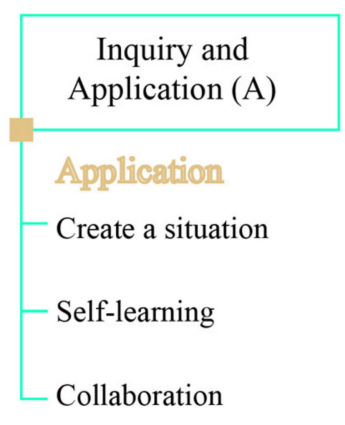

(b)

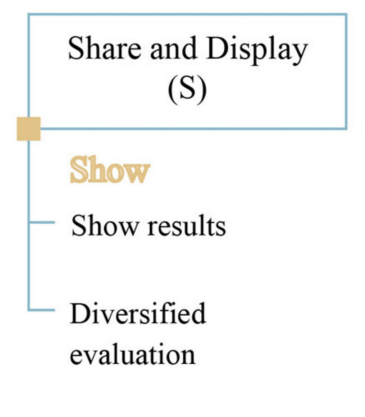

(c)

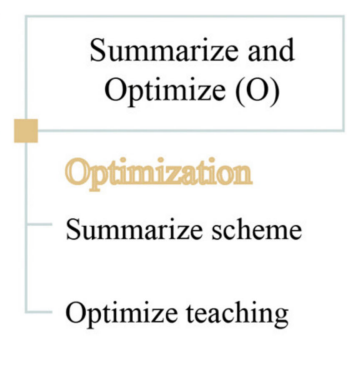

(d)

Figure 4. PASO Teaching Method: (a) Problem-driven (P), (b) Inquiry and Application (A), (c) Share and displaying (S), (d) Summarize and Optimize (O).

\section{Problem-driven $(\mathrm{P})$}

Teachers can consider linking RES with humanistic sentiments, social hot spots, and the trend of the times when setting the theme of RES courses. It is recommended to start with the energy issues in and around the social energy hotspots to make the theme of the course more realistic and materialized. It also enables students to discover and solve problems in their lives, and to explore the factors for sustainable development. Furthermore, the process of theme formation is also a process of looking for RES utilization issues with research value and within the scope of students' capabilities. The RES theory contained in the problem itself should be multi-disciplinary and profound.

\section{Inquiry and Application (A)}

The Inquiry and Application module is the core module that includes three stages: setting up the situation, autonomous learning, and teamwork. The context creation can stimulate students' interest and make them better understand the meaning of solving 
RES problems. When creating a situation, it is necessary to focus on the actual situation and add specific conditions for the problem. Teachers can refer to irrelevant factors that often appear in actual situations and have a significant impact on solving problems. The goal of autonomous learning is to change from passive learning to active learning driven by problems. Cultivating the habit of autonomous learning is also more conducive to the cultivation of RES awareness. Autonomous learning includes not only the activation and application of old RES knowledge but also the exploration and learning of new knowledge. The knowledge learned is in line with the multidisciplinary characteristics of RES integration. Teamwork is an inevitable result of project-based learning. The communication and interaction between team members can more intuitively promote the change of students' attitude and cognition towards RES, and at the same time create a relaxed and pleasant learning environment.

3 Share and displaying (S)

Sharing and displaying focuses on not only the presentation of results but also the sharing of experiences learned in the process of solving RES problems. Sharing is a shortcut to learning renewable energy-related skills and innovative thinking, and teachers should make full use of it. At the same time, the subjects, forms, and perspectives of the presentation are encouraged to be diversified. Under the premise of meeting the requirements of the RES theme, teachers should give students more freedom to play. For example, in the form of self-evaluation, mutual evaluation, and teacher evaluation, students are encouraged to use diversified forms such as videos and reports to reproduce scenes of innovative use of RES. Teachers should also consciously guide students to use technical media such as PPT and mind maps.

4 Summarize and Optimize $(\mathrm{O})$

The "Summarize and Optimize" stage assists teachers to optimize and adjust the original curriculum based on student feedback, overall grasp of the student, RES development trends, and industry needs after the completion of the current RES curriculum. The adjustment of teaching content such as the case design, terminology use, teaching time and key communication does a good job in knowledge network construction.

\subsubsection{The Template of Course Evaluating Process}

Compared to traditional subject education, RES education is a new type of education and its learning goals, teaching methods, and teaching content are constantly changing and improving with the development of RES technologies. RES curriculum evaluation is the assessment of students' energy cognition and skill mastery and is the basis for improving the teaching quality and selecting the teaching content. Therefore, the evaluation should be well-rounded ranging from processes to results and from theory to practice. However, most of the existing RES curriculum evaluation mechanisms follow the traditional result-based written tests, failing to consider the students' cognitive, emotional, and skill areas. In order to address this, a Multidimensional Evaluation Mechanism was established.

As shown in Figure 5, the mechanism is a comprehensive evaluation of students knowledge, skills, and attitudes towards RES, which is reflected in the diversity of the content, process, method, subject, and management of the evaluation. From the perspective of evaluation type, it focuses on formative evaluation and carries out corresponding evaluations based on continuous observation, recording, and testing of the entire process of the RES course. From the perspective of evaluation subject, in addition to teacher evaluation, student self-evaluation should be strengthened. On the one hand, students are guided to build a clear understanding of renewable energy knowledge; on the other hand, students' mutual assessment is promoted to enhance teamwork and communication skills. From the perspective of evaluation results, students can innovate through brainstorming, creative design, painting, invention, and simple experiments. 


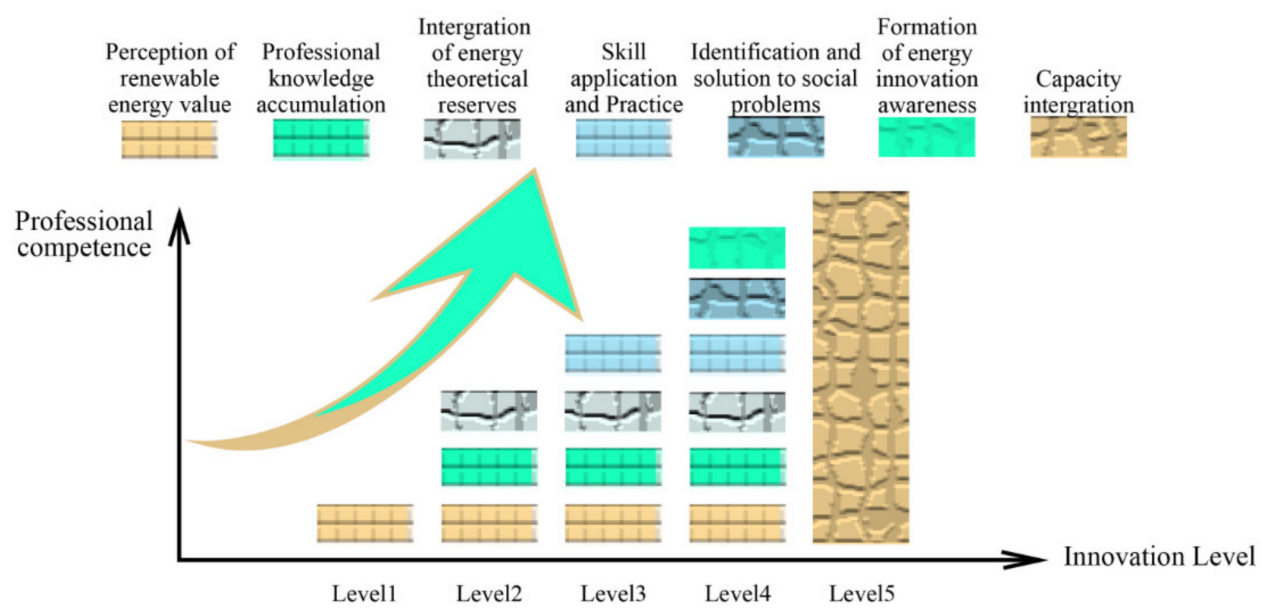

Figure 5. Multidimensional Evaluation Mechanism.

Establishing a diversified evaluation system is a necessary requirement for the realization of RES curriculum goals. It is not only necessary for realizing individualized teaching and developing students' personalities but also the need for multi-type, multi-standard and multi-level development of higher education. It is also of great significance to build a scientific evaluation system on the curriculum and student performance to improve the quality of renewable energy courses.

\section{Case Study-A Solar Sheet Handling Robot}

Solar energy has been widely used as a common renewable energy source, which drives the demand for solar panels. Through interviews with factory workers, it was found that the weight and operation difficulty of solar panels had a great impact on their work efficiency. According to the workers, the handling robots can not only improve product quality and productivity but also ensure the safety of themselves. Therefore, starting from the actual problems, we designed a solar panel handling robot course. According to the curriculum model proposed in Section 3, the course consists of three parts: design, teaching, and evaluation. Readers can use this case to expand ideas to have a more intuitive understanding of the application path of the RES curriculum model for college students. At the same time, we also conducted a series of quantitative experiments to verify the effectiveness of the course model.

\subsection{Focus on Design}

Table 1 shows the sections that need to be included in the curriculum design: curriculum value, teaching objectives, students' basic cognition, and curriculum resources. Establishing the curriculum based on students' existing knowledge helps to cultivate their innovative awareness while at the same time consolidate their knowledge base. In addition, the experimental settings and tools needed throughout the course are sorted out to create a high-quality environment for students to explore and innovate. 
Table 1. Case-Course Design.

Curriculum Name: "Solar Sheet Handling Robot"

I. Background of Research Study

Background: With the increasing application of solar power generation systems, the demand for solar panels is also increasing. According to the staff from the solar panel production line, the use of handling robots not only improves the quality and productivity but also has great significance in ensuring the safety of life, improving the working environment and production efficiency, and increasing economic benefits.

Significance and value of the project: Through this research, students can expand and consolidate relevant theoretical knowledge. Through the survey to understand the current innovative use of solar energy, especially the application of solar handling robots; through personal creation and development to improve the application of professional skills while training students' awareness of innovation and teamwork.

\begin{tabular}{|c|c|}
\hline Teaching Objectives of Research-based Learning & \\
\hline Knowledge and skills: & \\
\hline $\begin{array}{l}\text { To understand the classification of robots and the layout and } \\
\text { composition of workstations. }\end{array}$ & * To master the composition of the handling robot system. \\
\hline *To master common instructions for handling robots. & $\begin{array}{l}\text { * To learn how to use the teaching pendant to complete the I/O } \\
\text { configuration of solar panels for industrial robots. }\end{array}$ \\
\hline $\begin{array}{l}\text { To master the working steps and programming steps of the } \\
\text { handling robot. }\end{array}$ & $\begin{array}{l}\text { To learn how to use Robot Studio to complete the program writing } \\
\text { and debugging of industrial robot handling solar panel. }\end{array}$ \\
\hline
\end{tabular}

Process and methods:

* To experience the research process of identifying, analyzing, and solving problems, and initially learn the research methodology and study methods.

* To experience group learning, develop creative thinking and teamwork, and improve interpersonal skills.

* To learn the applications of relevant programming software as well as the workshop handling robots.

Emotional attitudes and values:

* To cultivate good habits of research and analysis, diligence, and innovation.

* To enhance students' ability to communicate and cooperate with each other.

III. Learner Characteristics

1. Students are sophomores.

2. Students have basic knowledge in programming, physics, and energy.

3. Students have some understanding of a series of experimental processes such as robot-making and data creation.

4. Students have strong interest in the innovative use of renewable energy and the development of intelligent robots.

\section{Research steps}

1. To learn and consolidate the theoretical knowledge related to physics, energy, and programming involved in the project.

2. To understand the working principle and application of the existing solar energy handling robots.

3. To select specific production workshops in units of groups, and then develop the handling robot.

4. Workstation and data creation.

5. Application and sharing of achievements.

6. Assessment of course learning process.

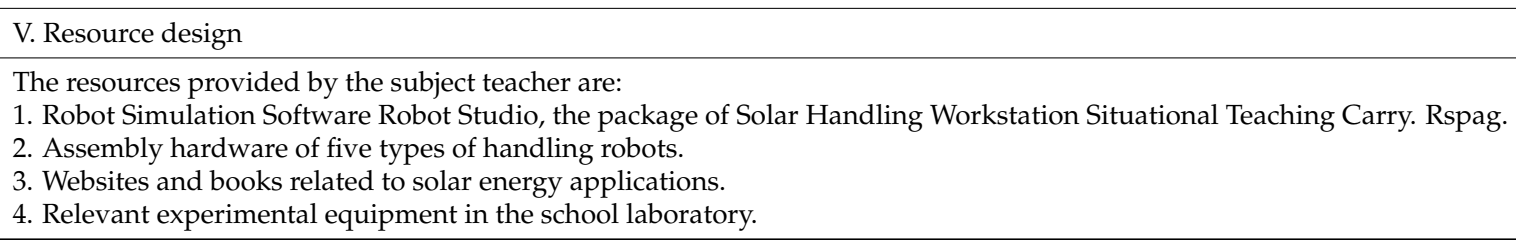

\subsection{Focus on Teaching}

In the teaching part, the teacher first introduced the current application of handling robots in daily life and identified the main problems related to the development of handling robots (Table 2). Then the teacher guided students to make suggestions for improvement according to their own interests by referring to relevant materials and conducting field visits. Before the actual operation, considering the multidisciplinary and applicability of the course, teachers should organize students to carry out necessary supplementary learning on existing theories to lay theoretical conditions for development. In the formal implementation, students were divided into groups and performed a reasonable division of labor within the group. The whole process was dominated by students. Teachers kept an eye on the progress and only provided inspiration and guidance in key links or difficulties. When the work was completed, students need to verify the effects, summarize the process and optimize the parts with poor performance. 
Table 2. Case-course teaching.

\begin{tabular}{|c|c|c|c|c|}
\hline \multicolumn{2}{|c|}{ Course Stage } & Student Activities & Teacher Activities & $\begin{array}{c}\text { Class } \\
\text { Schedule }\end{array}$ \\
\hline \multicolumn{2}{|c|}{$\begin{array}{l}\text { The first stage. Mobilization and training } \\
\text { phase (preliminary understanding of } \\
\text { research-based learning and research } \\
\text { methodology) }\end{array}$} & $\begin{array}{l}\text { 1. Establishing contact and } \\
\text { discussing issues. } \\
\text { 2. Understanding the purpose of } \\
\text { this activity. } \\
\text { 3. Learning and understanding the steps, } \\
\text { methods, and requirements of this } \\
\text { comprehensive practical activity. }\end{array}$ & $\begin{array}{l}\text { 1. Introducing the novel use of solar energy } \\
\text { to stimulate students' interest. } \\
\text { 2. Encouraging students to talk about } \\
\text { feelings and ask questions. }\end{array}$ & $2 \mathrm{~h}$ \\
\hline \multirow{5}{*}{$\begin{array}{l}\text { The second stage. } \\
\text { Course } \\
\text { preparation. }\end{array}$} & $\begin{array}{l}\text { Knowledge } \\
\text { supplement and } \\
\text { consolidation }\end{array}$ & $\begin{array}{l}\text { 1. Learning and consolidating relevant } \\
\text { theoretical knowledge to lay the } \\
\text { foundation for subsequent practical } \\
\text { innovation. } \\
\text { 2. Being good at thinking and asking } \\
\text { questions. }\end{array}$ & $\begin{array}{l}\text { Paving the theoretical knowledge that may } \\
\text { be involved for students according to their } \\
\text { specific situation. }\end{array}$ & \multirow{5}{*}{$4 \mathrm{~h}$} \\
\hline & Propose a topic & $\begin{array}{l}\text { 1. Discussing the application form of } \\
\text { solar energy and the development status } \\
\text { of solar handling robots. } \\
\text { 2. Through the discussions between } \\
\text { teachers and students, recognizing the } \\
\text { value of solar handling robots and } \\
\text { discovering the real problems. }\end{array}$ & $\begin{array}{l}\text { Introducing topics from the development } \\
\text { of solar energy and technological } \\
\text { development to allow students to } \\
\text { recognize the importance of solar sheet } \\
\text { handling robots and stimulate their ideas } \\
\text { for improvement and optimization. }\end{array}$ & \\
\hline & \multirow[b]{2}{*}{$\begin{array}{l}\text { Set up a research } \\
\text { group }\end{array}$} & $\begin{array}{l}\text { 1. Students determining their sub-select } \\
\text { based on their expertise and interests, } \\
\text { and forming groups accordingly. }\end{array}$ & $\begin{array}{l}\text { 1. On the premise that students are } \\
\text { voluntarily grouped, rationally allocating } \\
\text { members of each group so that students } \\
\text { with weak abilities can also be assigned } \\
\text { to work. }\end{array}$ & \\
\hline & & $\begin{array}{l}\text { 2. After the establishment of each group, } \\
\text { selecting the group leader and studying } \\
\text { and discussing the group's Cooperative } \\
\text { Learning Assessment Scale; } \\
\text { 3. According to the sub-select, carrying } \\
\text { out small group work and starting the } \\
\text { initial data collection and experiment } \\
\text { preparation. }\end{array}$ & $\begin{array}{l}\text { 2. Formulating cooperative learning rules } \\
\text { (or cooperative learning assessment } \\
\text { metrics) for students. }\end{array}$ & \\
\hline & $\begin{array}{l}\text { Form a group } \\
\text { implementation } \\
\text { plan }\end{array}$ & $\begin{array}{l}\text { Each group formulates a research plan } \\
\text { according to the work division, allocates } \\
\text { research time, refines research content, } \\
\text { and determines expected results. }\end{array}$ & $\begin{array}{l}\text { 1. Designing a "research plan" template to } \\
\text { provide guidance for students to formulate } \\
\text { a research plan. } \\
\text { 2. Designing result presentation template. }\end{array}$ & \\
\hline \multirow[t]{3}{*}{$\begin{array}{l}\text { The third stage. } \\
\text { Course } \\
\text { implementation. }\end{array}$} & Progress report & $\begin{array}{l}\text { When each phase is completed, make a } \\
\text { timely record and summary, and report } \\
\text { the progress regularly (creating } \\
\text { workstations, configuring system I / O, } \\
\text { creating program data, modifying the } \\
\text { handling program, and running } \\
\text { simulation of solar sheet handling). }\end{array}$ & \multirow{2}{*}{$\begin{array}{l}\text { 1. Distributing the "Experimental Record } \\
\text { Form" to the group leader for use as } \\
\text { information collation after each group's } \\
\text { experiment. } \\
\text { 2. Tracking and understanding the } \\
\text { experimental development process of each } \\
\text { group in time, and playing a guiding and } \\
\text { enlightening role when students encounter } \\
\text { bottlenecks. }\end{array}$} & \multirow[t]{3}{*}{$8 \mathrm{~h}$} \\
\hline & \multirow[b]{2}{*}{ Effect detection } & \multirow{2}{*}{$\begin{array}{l}\text { After the solar thin-plate robot works are } \\
\text { completed as a whole, the effect test is } \\
\text { performed in a simulated environment, } \\
\text { and a standardized project report is } \\
\text { generated to summarize and optimize. }\end{array}$} & & \\
\hline & & & $\begin{array}{l}\text { 3. Observing the participation of each } \\
\text { student and promptly motivating and } \\
\text { supervising those with low participation. }\end{array}$ & \\
\hline
\end{tabular}

1. Each group reports its research results in the last semester, in the form of PowerPoint, photos, handwritten reports, survey reports, short videos, etc.

The fourth stage. 2. Each team member completes the self-evaluation report, and Evaluation, the team leader is responsible for collecting and organizing these summary, and reports. reflection.
3. When the results of all groups are reported, each group comments and evaluates the results of the activities of other groups.

4. Finally, each member synthesizes the evaluation from the group, the teachers, and themselves.
Based on the activities of each group in one semester, the teacher uses the evaluation form 3 to give his/her evaluation comments and guidance through the entire activity process. 


\subsection{Focus on Evaluation}

In order to thoroughly evaluate the effectiveness of the course, the evaluation method was a comprehensive assessment of the final exam $(30 \%)+$ practical operation $(30 \%)+$ result display and application $(30 \%)+$ assignment $(5 \%)+$ attendance rate $(5 \%)$. The evaluation form also includes self-evaluation, mutual evaluation of members, and teacher evaluation. Table 3 shows the teacher's evaluation form on the student's performance. It can be clearly found that the evaluation stage ran across the entire process of the course. Compared with the traditional test, it focused on examining the practical application of relevant skills and the overall quality of students, which is more in line with the teaching objectives of RES courses. After the course, teachers also guided students to expand and apply knowledge. For example, in industrial production, loading robots are used on different occasions, and learning how to modify them to suit more working scenarios will stimulate students' research interest. At the same time, the teacher could obtain real-time feedback on the teaching effect of the course through questionnaires or direct communication with students and make real-time adjustments for better results. (a), (b) and (c) in Figure 6 show the students' works.

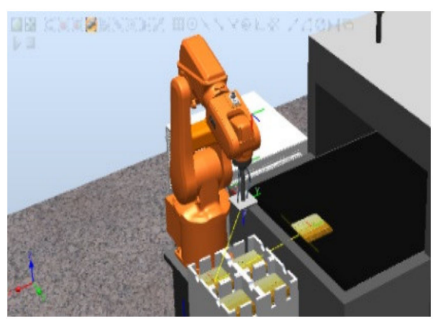

(a)

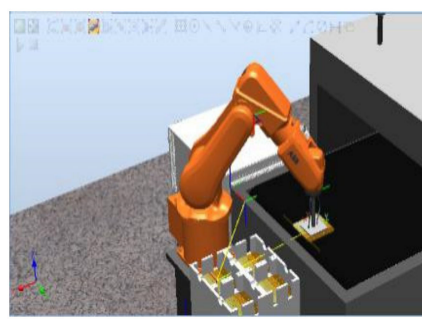

(b)

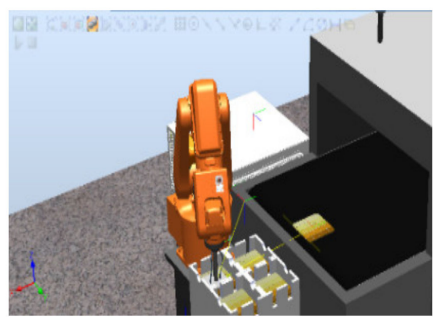

(c)

Figure 6. Student-Designed Solar-powered Robots.

Table 3. Teacher Evaluation Form.

\begin{tabular}{|c|c|c|c|c|c|c|}
\hline $\begin{array}{c}\text { Serial } \\
\text { Number }\end{array}$ & $\begin{array}{c}\text { Main } \\
\text { Content }\end{array}$ & Assessment Requirements & Standards for Evaluation & Partition & Deduction & Score \\
\hline \multirow{2}{*}{1} & \multirow{2}{*}{$\begin{array}{l}\text { Preview } \\
\text { before } \\
\text { training }\end{array}$} & \multirow{2}{*}{$\begin{array}{l}\text { Carefully reviews the } \\
\text { relevant knowledge of the } \\
\text { solar sheet handling robot } \\
\text { and completes the relevant } \\
\text { content in the training } \\
\text { instruction book. }\end{array}$} & $\begin{array}{l}\text { (1) } 10 \text { points will be deducted } \\
\text { if the training content is not } \\
\text { previewed before the training. }\end{array}$ & \multirow{2}{*}{10} & & \\
\hline & & & $\begin{array}{l}\text { (2) } 7 \text { points will be deducted if } \\
\text { not completing the training } \\
\text { instruction book. }\end{array}$ & & & \\
\hline 2 & $\begin{array}{l}\text { Workstation } \\
\text { creation }\end{array}$ & $\begin{array}{l}\text { Can correctly decompress, } \\
\text { backup, and warm-up the } \\
\text { program package of the } \\
\text { solar handling station. }\end{array}$ & $\begin{array}{l}\text { If unable to properly } \\
\text { decompress, backup or hot } \\
\text { start the package, } 5 \text { points will } \\
\text { be deducted for each item. }\end{array}$ & 15 & & \\
\hline 3 & $\begin{array}{l}\text { I/O Configu- } \\
\text { ration }\end{array}$ & $\begin{array}{l}\text { (1) Can configure the I/O } \\
\text { unit correctly. } \\
\text { (2) Can correctly configure } \\
\text { the I/O signals. } \\
\text { (3) Can configure the system } \\
\text { input and output correctly. }\end{array}$ & $\begin{array}{l}\text { If unable to configure the } \\
\text { MCU correctly, 5-10 points } \\
\text { will be deducted for each } \\
\text { item. }\end{array}$ & 15 & & \\
\hline 4 & $\begin{array}{l}\text { Program data } \\
\text { process of the } \\
\text { handling } \\
\text { robot system }\end{array}$ & $\begin{array}{l}\text { (1) Can create tool } \\
\text { data correctly. } \\
\text { (2) Can correctly create } \\
\text { workpiece coordinate data. } \\
\text { (3) Can correctly create } \\
\text { load data. }\end{array}$ & $\begin{array}{l}\text { 5-10 points will be deducted } \\
\text { for program data handling } \\
\text { system configuration errors. }\end{array}$ & 15 & & \\
\hline
\end{tabular}


Table 3. Cont.

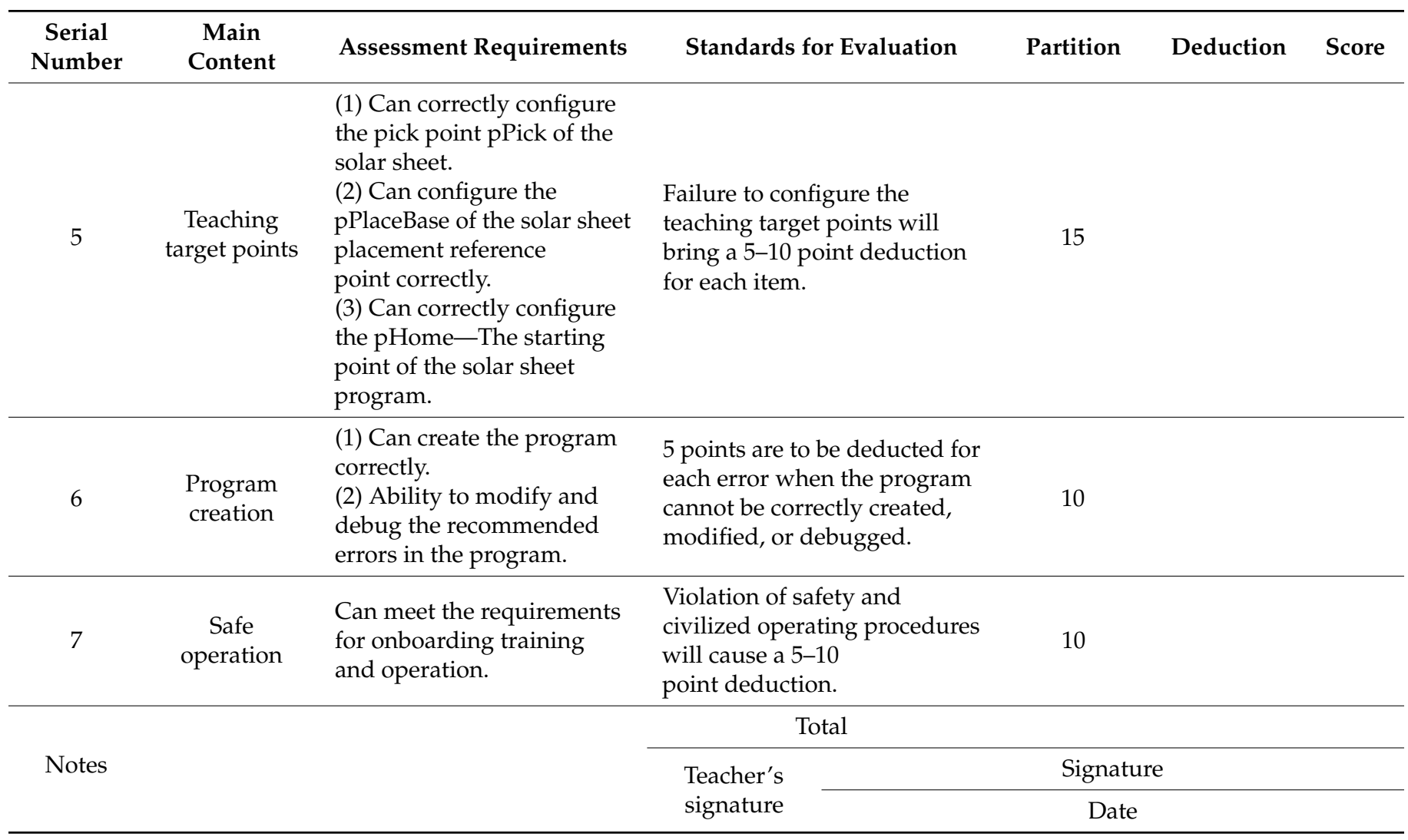

\subsection{Analysis of Course Effect}

\subsubsection{Quantitative Analysis of Course Effect}

In order to verify the teaching effect of the curriculum model, we adopted a quantitative method to reflect the changes in students' academic performance before and after learning. Since the research object needs to have a preliminary understanding of the RES course, we chose 27 sophomore students at the New Energy College of China University of Petroleum (East China) as the research object. The full score of the test is 50 points and the experiment produced a total of $27 * 2$ test copies (pre-test 27 , post-test 27 ), all of which are considered valid.

To start with, a paired $t$-test was conducted to determine whether the student's academic performance has been significantly improved. The results are shown in Table 4 . The $p$-value (two-tailed) of the mean value is close to zero $(\mathrm{t}=10.642, p$-value $=0.000)$. When the significance level is 0.05 , we should reject the null hypothesis, which indicated that the students' performance after the new RES curriculum model was significantly improved. It also shows that after excluding other unobserved variables, the new RES curriculum model had a statistically positive impact on the learning effect of students, with the average score of students increased by 15.63 points.

Table 4. Paired t-test for pre-test and post-test score variables.

\begin{tabular}{|c|c|c|c|c|c|c|c|c|}
\hline & \multicolumn{5}{|c|}{ Paired Differences } & \multirow{3}{*}{$\mathbf{t}$} & \multirow{3}{*}{ df } & \multirow{3}{*}{ Sig (2-Tailed) } \\
\hline & \multirow[t]{2}{*}{ Mean } & \multirow{2}{*}{$\begin{array}{c}\text { Std. } \\
\text { Deviation }\end{array}$} & \multirow{2}{*}{$\begin{array}{l}\text { Std. Error } \\
\text { Mean }\end{array}$} & \multicolumn{2}{|c|}{$\begin{array}{l}95 \% \text { Confidence Interval } \\
\text { of the Difference }\end{array}$} & & & \\
\hline & & & & Lower & Upper & & & \\
\hline $\begin{array}{l}\text { Post-test-pre-test } \\
\text { score }\end{array}$ & 15.630 & 7.632 & 1.469 & 12.611 & 18.649 & 10.642 & 26 & 0.000 \\
\hline
\end{tabular}


Next, students' basic knowledge could also affect the final score. We ranked the pre-test results from high to low and took the top 30\% students as high-achieving students and the last $30 \%$ students as low-achieving students. After calculating the gain average of the two groups as shown in Table 5, we used the independent $t$-test to analyze the difference between the two groups' gain average and the impact of the differences in the students' own foundation on the course effect, as shown in Table 6.

Table 5. Average scores for low-achieving and high-achieving groups.

\begin{tabular}{cccc}
\hline Group & Pre-Test Average & Post-Test Average & Gain Average \\
\hline High-achieving & 30.625 & 42.125 & 11.5 \\
Low-achieving & 17.375 & 38.5 & 21.125 \\
\hline
\end{tabular}

Moreover, the Levene's test for the equality of variances shows that $\mathrm{F}=19.220$, $p=0.001<0.05$, which suggested that we rejected the null hypothesis. In the lower row, $\mathrm{t}=-3.446$ and $p=0.006<0.05$, indicating that there was a significant difference in the 0.05 level between the two groups and the gain average of students with poor grades is 9.625 points higher than those with high grades.

Table 6. Independent $t$-test.

\begin{tabular}{|c|c|c|c|c|c|c|c|c|c|}
\hline & \multicolumn{2}{|c|}{$\begin{array}{c}\text { Levene's Test for } \\
\text { Equality } \\
\text { of Variances }\end{array}$} & \multicolumn{7}{|c|}{$t$-Test for Equality of Means } \\
\hline & \multirow[t]{2}{*}{$\mathbf{F}$} & \multirow[t]{2}{*}{ Sig } & \multirow[t]{2}{*}{$\mathbf{t}$} & \multirow[t]{2}{*}{ df } & \multirow{2}{*}{$\begin{array}{c}\text { Sig } \\
\text { (2-Tailed) }\end{array}$} & \multirow{2}{*}{$\begin{array}{c}\text { Mean } \\
\text { Difference }\end{array}$} & \multirow{2}{*}{$\begin{array}{c}\text { Std.error } \\
\text { Difference }\end{array}$} & \multicolumn{2}{|c|}{$\begin{array}{c}95 \% \text { Confidence Interval } \\
\text { of the Difference }\end{array}$} \\
\hline & & & & & & & & Lower & Upper \\
\hline $\begin{array}{l}\text { Equal variances } \\
\text { assumed }\end{array}$ & 19.220 & 0.001 & -3.446 & 14 & 0.004 & -9.625 & 2.793 & -15.616 & -3.634 \\
\hline $\begin{array}{l}\text { Equal variances } \\
\text { not assumed }\end{array}$ & & & -3.446 & 9.942 & 0.006 & -9.625 & 2.793 & -15.853 & -3.397 \\
\hline
\end{tabular}

\subsubsection{Significant Improvement of Students' Creativity}

Through the multi-angle evaluation of course effects, it is found that students' abilities have been improved in various aspects. At the same time, we interviewed five representative students to further investigate their recognition of their own ability changes. They all expressed their support: the application of renewable energy is a frontier and abstract issue that cannot be imagined in teachers' description alone. The new course would help them better understand and determine the future direction of renewable energy applications. This makes the course more attractive and makes a deep impression on them. The most impressive thing is that three students further created a new work based on solar panels, called "E-Go Robot", as shown in Figure 7. It is a solar panel moving with the sun. It can be found concluded that students are gradually mastering the ability to solve actual problems, which is an important reflection of their creativity improvement. We also kept the working videos of the students' work as supporting materials. 


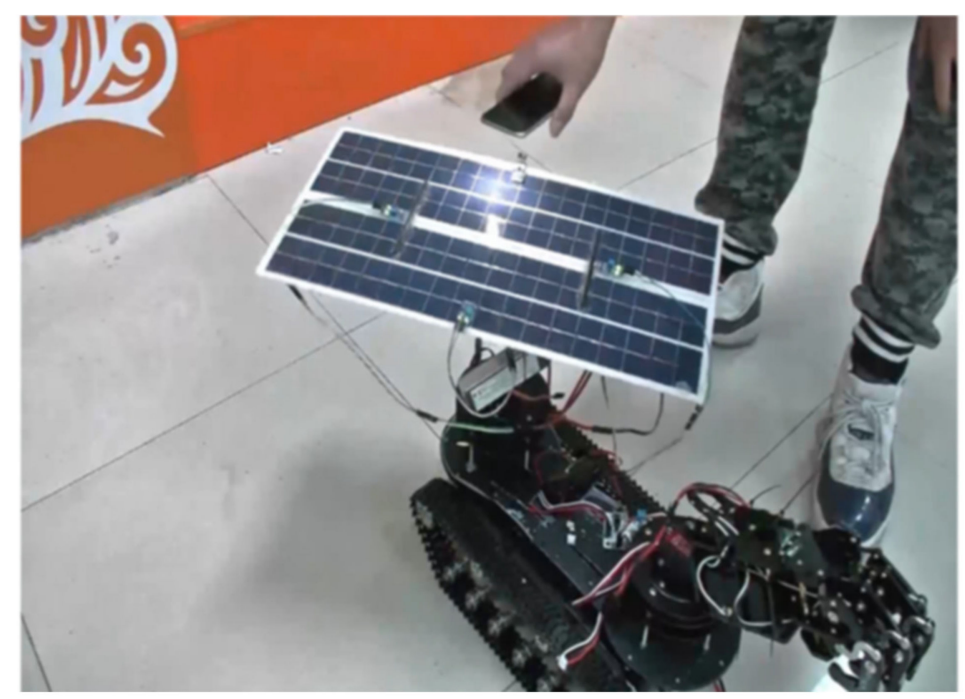

Figure 7. Student Designed Solar-powered Robot.

\section{Discussions and Conclusions}

\subsection{Preliminary Findings and Discussions}

The education of renewable energy in colleges could promote the implementation of the concept of sustainable development [53]. From the literature, it is obvious that sustainability is a key factor in higher education and many scholars have made joint efforts. Considering all kinds of barriers, it has become the key issue that how to integrate the concept of sustainable development education into the transformation of higher education. For teachers, in the process of remodeling teaching methods, we need a better entry point to insert the concept of sustainable development. For students, it could also realize the construction of knowledge through cooperative learning [54]. However, they are facing many obstacles, such as the lack of sustainable funding and financial incentives for educators [55-57]. Thus, it is necessary to take the renewable energy course as a specific case.

At the same time, we found from the existing cases that: First, the multiple combination evaluation method coincides with the interdisciplinary dimension analysis of cooperative learning [58]. The new RES curriculum model had significant supplemental learning effects. Meanwhile, through the course case "solar panel handling robot", it is found that students are gradually mastering the ability to solve actual problems and coming up with more in-depth and innovative ideas simultaneously, which shows their increased creativity. Second, the learning gains for low achievement students were higher than for high achieving students, which indicated that the new RES curriculum model is more effective for low achievement students and we further analyzed the possible reasons for this disparity: (a) High-achievement students had a high initial score and there was not much room for improvement. (b) The test questions are relatively basic, which were grasped well by high-achievement students at the beginning. (c) When the main goal of the course is to help students develop problem-solving skills and inquiry-based exploration skills rather than merely knowledge transfer, a simple paper-and-pencil test may not fully prove its effectiveness. This is also the reason why we adopted a multi-evaluation method in the evaluation process.

In future experiments, it might be much easier to get students' feedback on the course from direct inquiry. Finally, the new RES curriculum model focused on practical operations, which is expected to bring long-term memory effects to students through query-based observations and operations. However, the post-test was conducted immediately after the learning activity, so it is impossible to measure the long-term learning effectiveness. 


\subsection{Conclusions}

Based on the research results, this study sorts out the common problems that exist in the RES courses for Chinese college students and proposes an appropriate course model on renewable energy with a self-optimization mechanism. Lastly, the effectiveness of the model is verified through case teaching and quantitative analysis. The research data shows that the RES courses lack standardized integration as a whole. More importantly, there are key issues such as the content design is too subjective and broad, the teaching method is too old and unbalanced, and the evaluation focus is too theoretical and single. In order to solve the above problems and standardize the course process, this study aims at cultivating students' innovative use skills and awareness of renewable energy as the core goal, and based on the optimized and integrated traditional teaching theory, creates the "Student-centered Inquiry" course model on renewable energy. The model emphasizes the gradual nature of design, the autonomy of teaching, and the diversity of evaluation. Based on the three major links, the perform demonstration and standard guidelines for teachers are constructed respectively.

By case teaching and the analysis of performance between the early and late stages, we found that the new RES curriculum model is conducive to improving students' test scores and has a more significant impact on students with poor grades. Also, through interviews with students, it was found that after rebuilding the RES curriculum model, the teaching effect could be improved from the following four aspects:

(1) Knowledge transfer: the academic background requirements of multidisciplinary integration are met. Take the course on solar thermal utilization, for example, students need to have basic knowledge of heat transfer, thermodynamics, optics, and calculus. Another thing to note is the vertical depth of the course content. Universities can open elective courses for different branches of RES to arouse students' interest, provide space for development and stimulate their internal motivation.

(2) Methodology: RES courses are expected to be achieved through project-oriented research that is student-led, teacher-led, team-based, and problem-oriented. In addition to the regular RES courses, hiring professional RES engineers, scientists, technicians, and mechanics to give lectures in this area is an effective way to make up for subjective bias in the current curriculum.

(3) Reductionism: To exercise students' ability RES knowledge transfer and application by restoring the high-level theoretical knowledge to the low-level life problems, universities can establish links with local energy companies and research institutions to guide students to participate in scientific research, technology development, and promotion of other practical activities. Through these efforts to identify the current needs, and finally resolve the problem of course content deviating from actual demand.

(4) Consciousness formation: This is in line with the top goal of the RES curriculum, as attitudes and values for innovative development and utilization of resources are naturally formed in the process of discovering and solving problems arising from the actual renewable energy situation.

Finally, it should be noted that this study has two obvious limitations. On the one hand, the sum of the existing curriculum models' problems is based on the survey data. As we collected only some representative universities as survey samples but not covered the data from every university, some colleges' courses problems might be ignored. Second, participants in the course effectiveness verification experiment in this study were sampled from representative energy universities in China. Therefore, whether the model constructed in this study could be applied to universities in other regions could not be determined, especially some comprehensive universities.

In view of the current limitations of this study, the future research direction is to consider more driving factors, such as regional differences. A more standardized curriculum model can be adapted to renewable energy education at most universities. At the same time, future research will further test the effectiveness of the model in different contexts and make the targeted optimization. 
Author Contributions: Conceptualization, L.G.; methodology, X.W.; software, X.W.; validation, X.W.; formal analysis, X.W.; investigation, X.W. and L.G.; resources, X.W.; data curation, X.W. and L.G.; writing—original draft preparation, X.W.; writing—review and editing, L.G.; visualization, L.G. and X.W.; supervision, L.G.; project administration, X.W.; funding acquisition, L.G. All authors have read and agreed to the published version of the manuscript.

Funding: This research was supported by the Fundamental Research Funds for the Central Universities, grant number 18CX02111A and 20CX05021A and the Qingdao Source Innovation Program, grant number 19-6-2-60-cg, and the Major Scientific and Technological Projects of CNPC under Grant ZD2019-183 -004, and China University of Petroleum (East China) Postgraduate Innovation Project (YCX2020098).

Informed Consent Statement: Informed consent was obtained from all subjects involved in the study.

Conflicts of Interest: The authors declare no conflict of interest.

\section{References}

1. Melosi, M.V. Nuclear Power versus The Environment: The Bandwagon Market and the Energy Crisis. In Atomic Age America; Routledge: Abingdon, UK, 2016; pp. 236-271.

2. Qing, H. Main types and applications of hybrid power generation system. IOP Conf. Ser. Earth Environ. Sci. 2019, $300,042054$. [CrossRef]

3. Poudyal, R.; Loskot, P.; Nepal, R.; Parajuli, R.; Khadka, S.K. Mitigating the current energy crisis in Nepal with renewable energy sources. Renew. Sustain. Energy Rev. 2019, 116, 109388. [CrossRef]

4. Gorjian, S.; Zadeh, B.N.; Eltrop, L.; Shamshiri, R.R.; Amanlou, Y. Solar photovoltaic power generation in Iran: Development, policies, and barriers. Renew. Sustain. Energy Rev. 2019, 106, 110-123. [CrossRef]

5. Bosman, L.B.; Chelberg, K.A. Integrating Context and Authenticity to Increase Pre-College Engagement through the STEM Academy for Renewable Energy Education. Int. J. Pedagog. Innov. 2019, 7, 17-29.

6. Lucas, H.; Pinnington, S.; Cabeza, L.F. Education and training gaps in the renewable energy sector. Sol. Energy 2018, 173, 449-455. [CrossRef]

7. Ciriminna, R.; Meneguzzo, F.; Pecoraino, M.; Pagliaro, M. Reshaping the education of energy managers. Energy Res. Soc. Sci. 2016, 21, 44-48. [CrossRef]

8. Afkar, M.; Jebreilzadeh, M.; Gavagsaz-Ghoachani, R.; Phattanasak, M. A teaching method based on storytelling of a student social activity in renewable energy education. In Proceedings of the 2019 6th International Conference on Technical Education (ICTechEd6), Bangkok, Thailand, 19-20 March 2019.

9. Lee, L.; Lin, K.; Guu, Y.; Chang, L.; Lai, C. The effect of hands-on 'energy-saving house' learning activities on elementary school students' knowledge, attitudes, and behavior regarding energy saving and carbon-emissions reduction. Environ. Educ. Res. 2013, 19, 620-638. [CrossRef]

10. Guven, G.; Sulun, Y. Pre-service teachers' knowledge and awareness about renewable energy. Renew. Sust. Energ. Rev. 2017, 80, 663-668. [CrossRef]

11. Özmen, D.; Çetinkaya Nehir, A.Ç. Üniversite öğrencilerinin çevre sorunlarına yönelik tutumları. TSK Koruyucu Hekim. Bülteni 2005, 4, 330-344.

12. Zografakis, N.; Menegaki, A.N.; Tsagarakis, K.P. Effective Education For Energy Efficiency. Energy Policy 2008, $36,3226-3232$. [CrossRef]

13. Şimşekli, Y. Çevre Bilincinin Geliştirilmesine Yönelik Çevre Eğitimi Etkinliklerine İlköğretim Okullarının Duyarlılığı. 2004, pp. 83-92. Available online: http:/ / ucmaz.home.uludag.edu.tr/PDF/egitim/htmpdf/2004-17(1)/mak08.pdf (accessed on 28 January 2021).

14. Erten, S. Çevre eğitimi ve çevre bilinci nedir, çevre eğitimi nasıl olmalıdır. Çevre İnsan Derg. 2004, 65, 1-13.

15. Beynaghi, A.; Trencher, G.; Moztarzadeh, F.; Mozafari, M.; Maknoon, R.; Leal Filho, W. Future sustainability scenarios for universities: Moving beyond the United Nations Decade of Education for Sustainable Development. J. Clean. Prod. 2016, 112, 3464-3478. [CrossRef]

16. Ehrlich, R.; Geller, H. Renewable energy, second edition: A First Course; Taylor \& Francis Group: New York, NY, USA, 2017; pp. $1-490$.

17. Ocetkiewicz, I.; Tomaszewska, B.; Mróz, A. Renewable energy in education for sustainable development. The Polish experience. Renew. Sustain. Energy Rev. 2017, 80, 92-97. [CrossRef]

18. Stapleton, G.; Collins, R. Quality Renewable Energy Training Programs for Technicians. In 12th International Symposium on Renewable Energy Education; Fabio G.S. Giucastro: Strömstad, Sweden, 2017.

19. Otto, S.; Evans, G.W.; Moon, M.J.; Kaiser, F.G. The development of children's environmental attitude and behavior. Global Environ. Change 2019, 58, 101947. [CrossRef]

20. Bajpai, S.; Kidwai, N.R. Renewable Energy Education in India. Comp. Prof. Pedagog. 2017, 74, 103-113. [CrossRef] 
21. Alawin, A.A.; Abu Rahmeh, T.; Jaber, J.O.; Loubani, S.; Abu Dalu, S.; Awad, W.; Dalabih, A. Renewable energy education in engineering schools in Jordan: Existing courses and level of awareness of senior students. Renew. Sustain. Energy Rev. 2016, 65, 308-318. [CrossRef]

22. Qu, M.; Ahponen, P.; LiisaTahvanainen Gritten, D.; Mola-Yudego, B.; Pelkonen, P. Chinese university students' knowledge and attitudes regarding forest bio-energy. Renew. Sustain. Energy Rev. 2011, 15, 3649-3657. [CrossRef]

23. Chen, L.; Zhang, X.; Xu, X. Health Insurance and Long-Term Care Services for the Disabled Elderly in China: Based on CHARLS Data. Risk Manag. Healthc. Policy 2020, 13, 155-162. [CrossRef]

24. Kandpal, T.C.; Broman, L. Renewable energy education: A global status review. Renew. Sustain. Energy Rev. 2014, 34, 300-324. [CrossRef]

25. Li, X.; Tan, H.; Rackes, A. Carbon footprint analysis of student behavior for a sustainable university campus in China. J. Clean. Prod. 2015, 106, 97-108. [CrossRef]

26. Ramos, T.B.; Caeiro, S.; Van Hoof, B.; Lozano, R.; Huisingh, D.; Ceulemans, K. Experiences from the implementation of sustainable development in higher education institutions: Environmental Management for Sustainable Universities. J. Clean. Prod. 2015, 106, 3-10. [CrossRef]

27. Cao, X.; Kleit, A.; Liu, C. Why invest in wind energy? Career incentives and Chinese renewable energy politics. Energy Policy 2016, 99, 120-131. [CrossRef]

28. Wang, J.C.; Dai, L.; Tian, Y.S.; Qin, S. Analysis of the development status and trends of biomass energy industry in China. Nongye Gongcheng Xuebao/Trans. Chin. Soc. Agric. Eng. 2007, 23, 276-282.

29. Hasnain, S.M.; Alawaji, S.H.; Elani, U.A. Solar energy education-a viable pathway for sustainable development. Renew. Energy 1998, 14, 387-392. [CrossRef]

30. Yuan, X.; Feng, Y.; Qiu, Y. The present status and challenges of wind energy education and training in China. Renew. Energy 2013, $60,34-41$.

31. Ntona, E.; Arabatzis, G.; Kyriakopoulos, G.L. Energy saving: Views and attitudes of students in secondary education. Renew. Sustain. Energy Rev. 2015, 46, 1-15. [CrossRef]

32. Malkki, H.; Alanne, K.; Hirsto, L. A method to quantify the integration of renewable energy and sustainability in energy degree programmes: A Finnish case study. J. Clean. Prod. 2015, 106, 239-246. [CrossRef]

33. Wojuola, R.N.; Alant, B.P. Sustainable development and energy education in Nigeria. Renew. Energy 2019, 139, 1366-1374. [CrossRef]

34. Swift, A.; Tegen, S.; Acker, T.; Manwell, J.; Pattison, C.; McGowan, J. Graduate and undergraduate university programs in wind energy in the United States. Wind Eng. 2019, 43, 35-46. [CrossRef]

35. Sammalisto, K.; Sundstr M, A.; Holm, T. Implementation of sustainability in universities as perceived by faculty and staff-A model from a Swedish university. J. Clean. Prod. 2015, 106, 45-54. [CrossRef]

36. Von Blottnitz, H.; Case, J.M.; Fraser, D.M. Sustainable development at the core of undergraduate engineering curriculum reform: A new introductory course in chemical engineering. J. Clean. Prod. 2015, 106, 300-307. [CrossRef]

37. Sinnema, C.; Meyer, F.; Aitken, G. Capturing the Complex, Situated, and Active Nature of Teaching Through Inquiry-Oriented Standards for Teaching. J. Teach. Educ. 2016, 68. [CrossRef]

38. Dobber, M.; Zwart, R.; Tanis, M.; Van Oers, B. Literature review: The role of the teacher in inquiry-based education. Educ. Res. Rev. 2017, 22, 194-214. [CrossRef]

39. Miller, J.L.; Others, A. Review and Evaluation of DOE Energy Education Curriculum Materials. 1979; p. 10. Available online: https:/ / eric.ed.gov/?id=ED179423 (accessed on 29 May 2020).

40. Kalaani, Y. A Solar System Project to Promote Renewable Energy Education. Available online: https://peer.asee.org/15382 (accessed on 29 May 2020).

41. Yazici, M.S. Hydrogen and fuel cell activities at UNIDO-ICHET. Int. J. Hydrog. Energy 2010, 35, 2754-2761. [CrossRef]

42. Yazici, M.S. Hydrogen and Fuel Cell Educational Activities in Turkey. Energy Procedia 2012, 29, 690-694. [CrossRef]

43. Mcgowan, A.H. Renewable Energy: An Interdisciplinary Problem Solving Course. J. Syst. Cybern. Inform. 2013, 11. Available online: http:/ / www.iiisci.org/journal/CV\$/sci/pdfs/HRE215XQ.pdf (accessed on 29 May 2020).

44. Kotilainen, K.; Saari, U.A.; Mäkinen, S.J.; Ringle, C.M. Exploring the microfoundations of end-user interests toward co-creating renewable energy technology innovations. J. Clean. Prod. 2019, 229, 203-212. [CrossRef]

45. Wang, X.; Xu, W.; Guo, L. The Status Quo and Ways of STEAM Education Promoting China's Future Social Sustainable Development. Sustainability 2018, 10, 1-15. [CrossRef]

46. Kimuli, D.; Nabaterega, R.; Banadda, N.; Kabenge, I.; Ekwamu, A.; Nampala, P. Advanced Education and Training Programs to Support Renewable Energy Investment in Africa. Int. J. Educ. Pract. 2017, 5, 8-15.

47. Cope, B.; Kalantzis, M. e-Learning Ecologies: Principles for New Learning and Assessment; Routledge: Abingdon, UK, 2017.

48. Xu, X.; Chen, L. Projection of Long-Term Care Costs in China, 2020-2050: Based on the Bayesian Quantile Regression Method. Sustainability 2019, 11, 3530. [CrossRef]

49. Denek, K. Przewodnik po świecie wiedzy, wartości i życia, Kompetencje nauczyciela edukacji początkowej, por red. K. K. Żegnatka, Warszawa 2008.

50. Xu, X.; Zhang, L.; Chen, L.; Liu, C. The Role of Soil $\mathrm{N}_{2} \mathrm{O}$ Emissions in Agricultural Green Total Factor Productivity: An Empirical Study from China around 2006 when Agricultural Tax Was Abolished. Agriculture 2020, 10, 150. 
51. González-Zamar, M.D.; Abad-Segura, E. Implications of Virtual Reality in Arts Education: Research Analysis in the Context of Higher Education. Educ. Sci. 2020, 10, 225. [CrossRef]

52. Baldrighi, E.; Giovannelli, D.; D’Errico, G.; Lavaleye, M.; Manini, E. Exploring the Relationship between Macrofaunal Biodiversity and Ecosystem Functioning in the Deep Sea. Front. Mar. Sci. 2017, 4, 00198.

53. Leal Filho, W. Education for Sustainable Development in Higher Education: Reviewing Needs//Transformative Approaches to Sustainable Development at Universities; Springer: Cham, Switzerland, 2015; pp. 3-12.

54. Lenkauskaitė, J.; Colomer, J.; Bubnys, R. Students' Social Construction of Knowledge through Cooperative Learning. Sustainability 2020, 12, 9606. [CrossRef]

55. Ferrer-Balas, D.; Buckland, H.; de Mingo, M. Explorations on the University's role in society for sustainable development through a systems transition approach. Case-study of the Technical University of Catalonia (UPC). J. Clean. Product. 2009, 17, 1075-1085. [CrossRef]

56. Fisher, P.B.; McAdams, E. Gaps in sustainability education. Int. J. Sustain. High. Educ. 2015, 16, 407-423. [CrossRef]

57. Velazquez, L.; Munguia, N.; Platt, A.; Taddei, J. Sustainable university: What can be the matter? J. Clean. Product. 2006, 14, 810-819. [CrossRef]

58. Cañabate, D.; Garcia-Romeu, M.L.; Menció, A.; Nogué, L.; Planas, M.; Solé-Pla, J. Cross-Disciplinary Analysis of Cooperative Learning Dimensions Based on Higher Education Students' Perceptions. Sustainability 2020, 12, 8156. 